Relations industrielles

Industrial Relations

\title{
Powerful Community Relationships and Union Renewal in Australia
}

\author{
La construction de liens avec la communauté et le renouveau \\ syndical en Australie \\ Relaciones poderosas con la comunidad y renovación sindical \\ en Australia
}

\section{Amanda Tattersall}

Volume 61, numéro 4, automne 2006

Pistes de renouveau syndical : défis et enjeux

Paths to Union Renewal: Challenges and Issues

URI : https://id.erudit.org/iderudit/014762ar

DOI : https://doi.org/10.7202/014762ar

Aller au sommaire du numéro

Éditeur(s)

Département des relations industrielles de l'Université Laval

ISSN

0034-379X (imprimé)

1703-8138 (numérique)

Découvrir la revue

Citer cet article

Tattersall, A. (2006). Powerful Community Relationships and Union Renewal in Australia. Relations industrielles / Industrial Relations, 61(4), 589-614. https://doi.org/10.7202/014762ar

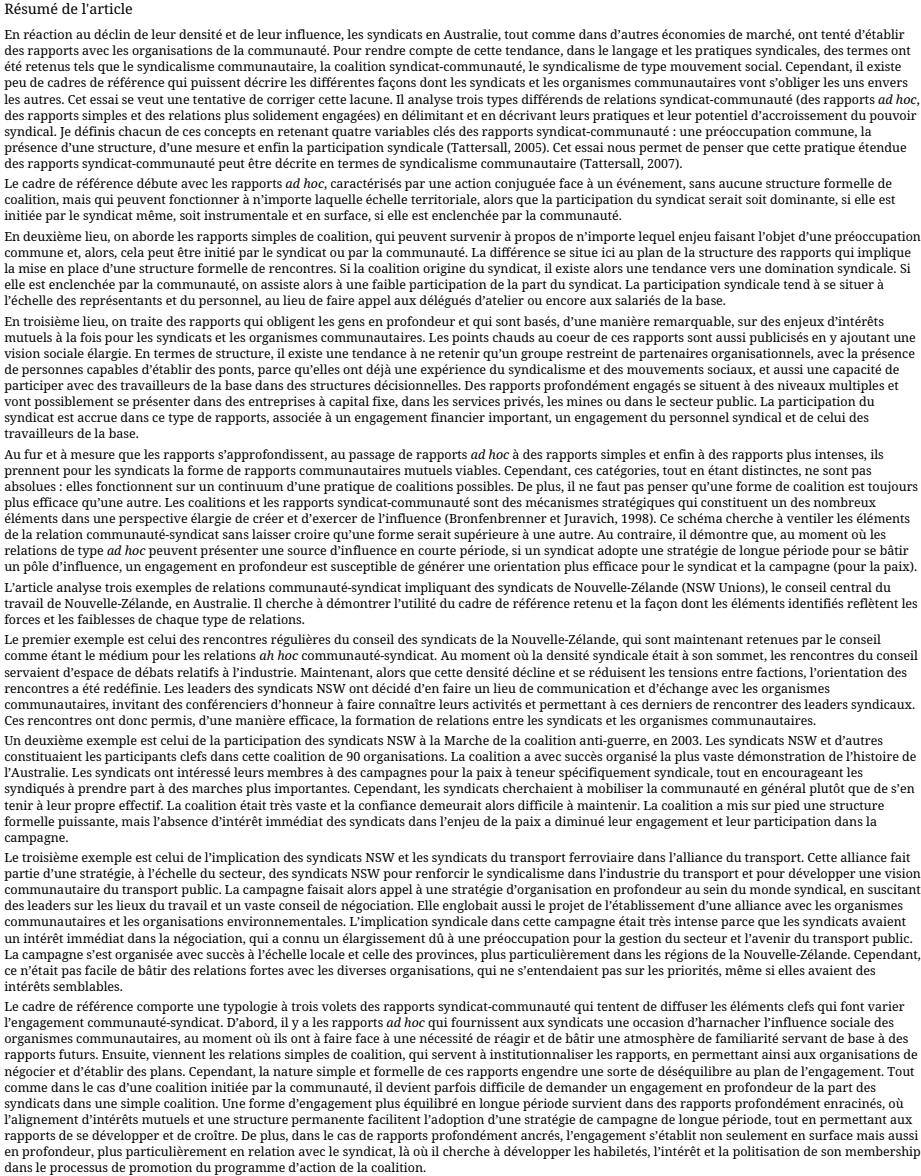

Ce document est protégé par la loi sur le droit d'auteur. L'utilisation des services d’Érudit (y compris la reproduction) est assujettie à sa politique d'utilisation que vous pouvez consulter en ligne.

https://apropos.erudit.org/fr/usagers/politique-dutilisation/
Tous droits réservés (C Département des relations industrielles de l'Universite Laval, 2006
Cet article est diffusé et préservé par Érudit.

Érudit est un consortium interuniversitaire sans but lucratif composé de l’Université de Montréal, l'Université Laval et l'Université du Québec à Montréal. Il a pour mission la promotion et la valorisation de la recherche. https://www.erudit.org/fr/ 


\title{
Powerful Community Relationships and Union Renewal in Australia
}

\author{
Amanda TAtTersall
}

Terms such as labour-community coalitions, community unionism and social movement unionism are important features of current strategies for union renewal. This article develops a threepart framework of union-community relationships, from ad hoc to deeply engaged relationships. Criteria such as common interest, coalition structure, scale and union participation are identified as important variables for relationship variation and campaign success. The article explores the framework by analyzing three case studies from Sydney, Australia, involving the central labour council-Unions NSW. The paper argues that union-community relationships vary significantly; ad hoc relationships are useful to react to a crisis while deeper relationships are most useful to build a long-term agenda. Deeper relationships are supported when they are built alongside a process of internal union renewal. Deeper relationships are more successful if unions develop workplace leaders, support political union education and provide space for workplace stewards to connect to community campaigns.

Across the industrialized world, unions are in a state of change. In Australia, the need for change arises from a dramatic decline in union density, and more recently, a dramatic anti-union legislative agenda that is threatening the capacity for collective bargaining and the power of unions in the workplace. Over the last 10 years, unions have experimented with union renewal, particularly focusing on new organizing strategies that enhance the capacity for workplace leadership development and growth. Supplementing this commitment to organizing is an evolving discussion around relationships between unions and community organizations, in particular union relationships with community organizations.

- Tattersall, A., School of Business, University of Sydney, amandatattersall@ gmail.com 
This article examines the broad trend of unions and community organizations working together, what I term community unionism (Tattersall, 2006c). Union relationships with community organizations have developed as a tactical response to declining union power and where employer hostility and anti-union laws are narrowing the capacity for traditional forms of union action.

While terms such as community unionism, union-community coalitions and social movement unionism have surfaced, there are few analytical frameworks that describe the different ways in which unions and community organizations engage with each other. This article seeks to bridge that gap. It discusses three different types of union-community relationships, defining and describing their practice and their potential to enhance union power. It begins with a discussion of three different types of union-community relationships-ad hoc relationships, simple relationships and deeply engaged relationships. Then, I consider three case studies of community unionism involving Unions NSW, the peak trade union council in Sydney, NSW. The article discusses the strengths and weaknesses of three examples of union-community relationships that parallel the types of relationships identified in the framework.

\section{A TYPOGRAPHY OF UNION RELATIONSHIPS WITH COMMUNITY ORGANIZATIONS}

Union relationships with community organizations can vary from $\mathrm{ad}$ hoc engagements to deeply engaged relationships. This section establishes a framework that describes and categorizes the different levels of unioncommunity relationships, and their strengths and weaknesses for building union power.

\section{Ad Hoc Relationships}

Many relationships between unions and community organizations begin and end briefly, where engagement is simple and distant. These ad hoc relationships focus on one-off requests for support, participation in events (such as a picket line or rally) or financial assistance. These relationships often occur in reaction to a crisis, where a crisis is turned into a political opportunity to reach out to like-minded organizations and ask for support (Tarrow, 1994).

Ad hoc relationships present tactical opportunities and strategic weaknesses for unions (Tattersall, 2005). They can provide a useful source of external power and support to confront immediate crises. Yet, the episodic and centralized nature of any engagement limits union connection 
to the community organization, because the relationship is often limited to union leaders, separate from union members. If these instrumental and transactional relationships are repeated and one-sided, they may create animosity between partners, where a community organization feels used rather than equal. Similarly, repeated requests by community organizations to unions for financial support may also produce resentment over time.

The episodic nature of this type of relationship limits its potential, yet it signifies an important step in union and community organization practice. Ad hoc relationships represent a desire for alignment, signalling the possibility of deeper coalition practice. While the power of an ad hoc relationship lies in the capacity for a short-term reaction, it also may provide the potential for future action by creating possibilities for solidarity. Ad hoc relationships are regularly a first step towards stronger collaboration.

\section{Simple Coalition Relationships}

The term labour-community coalition is frequently used to describe short-term, structured relationships between unions and community organizations (Brecher and Costello, 1990a; Tufts, 1998; Reynolds, 2004). I use the term simple coalition relationship to define the type of relationship that underpins these basic, issue-based coalitions.

Scholarship on union-community coalitions is broad and descriptive, trying to capture all possible variations in style and practice (Craft, 1990; Brecher and Costello, 1990a; Banks, 1992). This suggests union-community coalitions can be staged on any issue, from a union issue such as a strike, to a community issue such as health care or climate change. It also suggests that coalition relationships have a variable structure, operating within a 'coalitional' structure or inside a particular organization (Banks, 1992). These coalitions tend to not pay close attention to scale, geography or local capacity, operating at any spatial level, from the local, city-wide, national or international (Lipsig-Mumme, 2003; Tattersall, 2005). In their attempt to descriptively cover the field of coalition practice, scholars often emphasize the formal attributions of coalitions instead of the informal mechanisms and inequalities that underpin the relationships within simple coalitions. In practice, coalitions are often characterized by unequal participation and influence, tending to be dominated by either unions or community organizations. Union initiated coalitions tend to be union dominated, where unions informally control the strategic decision making, involving coalition partners in event planning rather than agenda setting (Munck and Waterman, 1999; Fine, 2003; Nissen, 2004a, 2004b; Tattersall, forthcoming a). Community initiated coalitions tend to struggle to build union participation, often only attracting junior staff to decision making meetings and achieving 
limited union engagement, aside from some commitment to mobilization (Clawson, 2003; Nissen, 2004a, 2004b; Tattersall, forthcoming b).

A key weakness of simple coalitions is their ability to balance union and community organization participation. Unfortunately, union scholarship provides limited guidance for understanding what type of internal union practices or types of issues contribute to more effective coalition relationships. Simple coalitions are staged on many issues, and there is often little regard to the types of issues that politicize, engage and develop members (Tattersall, 2005). Furthermore, reliance on a coalition structure limits deep participation by unions (Clawson, 2003). Alone, the coalition form provides little opportunity for workplace stewards to be involved in decision-making, as decision-making is limited to officials. Without ownership over the direction of the coalition, it is difficult to spark local organizing amongst union members inside unions on community issues.

Simple coalition relationships create opportunities for unions and community organizations to learn about each other through the process of campaigning together on issues of common concern (Obach, 2004). However, these relationships are limited by the mode of union engagement - through select officials, and because they often struggle to deeply and directly engage union interest and commitment.

\section{Deeply Engaged Relationships}

I use the term deeply engaged relationships to explore the features of union-community relationships where the engagement is more long term, where there is greater integration between the organizations and where union participation in particular is enhanced.

Deeply engaged relationships between unions and community organizations are most sharply distinguished from simple coalition relationships by the type of union participation. Unions are often considered to play a special role in coalitions because they usually have the largest membership and greatest resources amongst coalition partners (Nissen, 2004a, 2004b; Obach, 2004; Tattersall, 2005). Union participation occurs at two levels, externally with the coalition and internally within the union.

With regard to external participation, Nissen argues that union buy-in to coalitions is a central determinant of their success (Nissen, 2000, 2004a). He argues 'buy-in' is evidenced by a union's willingness to mobilize in support of a campaign, the seniority and number of members or officials it gets involved in the coalition's decision making structure and its willingness to provide financial resources. The greater the buy-in, the greater the effectiveness of the union-community coalition (Nissen, 2000, 2004a). 
Internally, the structure, strategy and agenda of the participating union also affect the type of relationships it engages in. Some criticize the limitations of 'business unionism', where the concerns of wages and conditions and practice of collective bargaining overshadow broader community concerns (Moody, 1997; Eisenscher, 1999). An internal process of union renewal is suggested, where unions broaden their vision and the range of issues they deem important, involve their members more actively in decision making and campaign selection, undertake union education that includes political education as well as union skills, and mobilize around the issues supported by the coalition (Nissen, 2000; Waterman, 1999; Tattersall, 2006b). To engage in deep relationships with community organizations requires a more open union practice, where unions develop and support delegate and steward involvement in coalition practice and where a social vision is embraced (Waterman and Wills, 2001; Freeman and Rogers, 2002; Wills, 2002; Clawson, 2003).

Deeply engaged relationships between unions and community organizations require a more reciprocal and trusting coalition structure (Tufts, 1998; Nissen, 2000, 2004b; Fine, 2003). Relationships of trust often develop as a product of more ad hoc or simple coalitions, where familiarity breads predictability (Lipsig-Mumme, 2003; Tattersall, 2006a). This may be assisted by equal decision making processes where unions and community organizations are treated as equals (Tufts, 1998). Deep coalitional relationships may also develop amongst a narrower category of partners, where coalition partners are hand-picked rather than found by inviting the largest possible constituency (Tattersall, 2005). This relationship of trust may not only include formal equal participation, but the participation of individual bridge-builders who have experiences in both community organizations and unions, who can help translate contrasting organizational and cultural practices (Estabrook, Siqueira et al., 2000; Rose, 2000). A flat coalitional structure may assist the coalition participants to negotiate and share the power they bring to the table, for instance, maximizing the political and social power of community representatives combined with a union's capacity to exercise economic power (Fine, 2003; Tattersall, 2006c). Some argue that while a coalition structure is necessary, it is not sufficient. They argue that deeply engaged organizational relationships also must allow individuals to participate in the structure, which may occur in a central coalition or partner coalitions operating at other scales, such as the local (De Martino, 1999; Clawson, 2003; Tattersall, 2006a).

Deeply engaged relationships may not lend themselves well to crisis situations; they are more likely to develop over issues that are in the mutual long-term self-interest of unions and community organizations. When the issues at the heart of a coalition are in the mutual self-interest 
of participating organizations, then it is more likely that there will be significant organizational commitment to the coalition, making the coalition more effective (Brecher and Costello, 1990b; Clawson, 2003; Fine, 2003). For unions, this would mean that the types of issues selected would be more likely to be in the direct, material self-interest of the membership, such as teachers campaigning on public education (Tattersall, 2007).

Deeply engaged relationships are most powerful if they operate at multiple scales, that is, they have the ability to operate at the local, provincial and national scales simultaneously (Ellem, 2005; Tattersall, 2005). Multiscalar action is powerful for achieving political outcomes, as well as for building internal organizational capacity. Externally, corporate and political decisions are made at multiple scales; politicians represent individual ridings (electorates) as well as forming a provincial or national government. While corporations can often move capital internationally, access to labour and corporate investment ties corporations to more local scales (Herod, 1998). In particular, it is argued that industries with a 'spatial fix' where service consumption or resource extraction is fixed to a particular location, such as mining or in human service work such as cleaning or transportation, provide unions with the ability to powerfully influence capital at a local scale (Johnston, 1994; Savage, 1998; Walsh, 2000; Ellem, 2003). In addition, multi-scalar activity not only requires unions to organize union members, but to organize power from local communities, such as through locallybased union-community coalitions (Jonas, 1998; Walsh, 2000). Local action may also be effective because it can allow for the direct participation by the union rank and file (Wills, 2002). If a coalition can deeply engage its union and community organization members to take action locally as well as at the scale of the state, then it can both enhance the depth of engagement and the capacity for political success.

Deeply engaged relationships occur when a breadth of activity between unions and community organizations is complemented by a depth of activity within participating unions. These forms of relationships offer the greatest capacity for long-term coalitions, as they create mutually interested relationships that can enhance the capacity of all participants. They will not always be a useful strategy, as the need for pre-existing relationships and interest alignment is difficult to build quickly. However, deep relationships have the capacity to nurture union renewal, as they support a form of unionism open to a broad issue agenda and the deep engagement of workplace leaders.

\section{A Typography of Union-Community Relationships}

Section one categorized three different ways in which unions and community organizations engage. It argued that each of these alignments 
offers potential power for unions, but the capacity for ongoing sustainable and deep relationships is more readily achieved through deeper engagement. They are outlined in Figure 1.

\section{FIGURE 1}

\section{A Typography of Union-Community Relationships}

\begin{tabular}{|c|c|c|c|}
\hline & Ad Hoc Relationship & $\begin{array}{l}\text { Simple Coalition } \\
\text { Relationship }\end{array}$ & $\begin{array}{l}\text { Deeply Engaged } \\
\text { Relationship }\end{array}$ \\
\hline $\begin{array}{l}\text { Common } \\
\text { concern }\end{array}$ & $\begin{array}{l}\text { - Relationship } \\
\text { occurs around an } \\
\text { event } \\
\text { - Union or } \\
\text { community } \\
\text { initiated }\end{array}$ & $\begin{array}{l}\text { - Relationship occurs } \\
\text { around any issue } \\
\text { - Union or community } \\
\text { initiated }\end{array}$ & $\begin{array}{l}\text { - Issues of mutual self- } \\
\text { interest to participating } \\
\text { organizations } \\
\text { - Issues framed as a broad } \\
\text { social vision }\end{array}$ \\
\hline Structure & $\begin{array}{l}\text { - Single, one off } \\
\text { requests } \\
\text { - No formal or } \\
\text { ongoing structure } \\
\text { to the relationship }\end{array}$ & $\begin{array}{l}\text { - Formal meeting } \\
\text { structure for decision } \\
\text { making } \\
\text { - If union initiated, } \\
\text { union dominated } \\
\text { - If community } \\
\text { initiated, limited union } \\
\text { participation }\end{array}$ & $\begin{array}{l}\text { - Unions and community } \\
\text { organizations involved } \\
\text { in joint decision-making } \\
\text { structure } \\
\text { - Relationships of trust and } \\
\text { reciprocity } \\
\text { - Bridge builders help } \\
\text { overcome cultural } \\
\text { barriers between } \\
\text { organizations } \\
\text { - Organizations invited to } \\
\text { participate } \\
\text { - Capacity for individual / } \\
\text { rank and file participation }\end{array}$ \\
\hline Place & $\begin{array}{l}\text { - Organized at any } \\
\text { scale, e.g., local, } \\
\text { city, global }\end{array}$ & $\begin{array}{l}\text { - Relationships can be at } \\
\text { any level: local, city- } \\
\text { wide, state, national, } \\
\text { international }\end{array}$ & $\begin{array}{l}\text { - Multi-scalar capacity } \\
\text { - Capacity to act locally } \\
\text { More likely in industries } \\
\text { where capital is fixed, } \\
\text { e.g., services, mining, } \\
\text { public sector }\end{array}$ \\
\hline $\begin{array}{l}\text { Union } \\
\text { participation }\end{array}$ & $\begin{array}{l}\text { - Instrumental } \\
\text { participation only }\end{array}$ & $\begin{array}{l}\text { - Union officials } \\
\text { participate, if } \\
\text { community initiated, } \\
\text { junior staff participate } \\
\text { - Instrumental } \\
\text { participation } \\
\text { - Campaign separate/ } \\
\text { distant from members }\end{array}$ & $\begin{array}{l}\text { - Union buy-in to planning } \\
\text { process } \\
\text { - Union vision beyond } \\
\text { wages and conditions } \\
\text { - Union members active } \\
\text { participants in coalition } \\
\text { events, and in some } \\
\text { decision making }\end{array}$ \\
\hline
\end{tabular}

These different categories serve to link variations in community union relationships to a framework that reveals the extent to which this practice enhances coalition and union power. It is important to note that these 
categories are distinct, but not absolute-they operate across a continuum of possible coalition practice. Furthermore, it should not be taken that one form of coalition is always 'more powerful' than another. Coalitions and union-community relationships are strategic devises that form one of many elements in a comprehensive plan to build and exercise power (Bronfenbrenner and Juravich, 1998). This schema attempts to break down the elements of union community relationships without necessarily privileging one form as 'better' than other. Rather, it highlights that while ad hoc relationships may provide a short-term source of power, if a union is embarking on a long-term strategy for power building, a deeper engagement is more likely to create a more powerful alignment for the campaign and for the union.

\section{THREE CASE STUDIES OF UNION-COMMUNITY RELATIONSHIPS INVOLVING UNIONS NSW}

These different categories can be explored and their strengths and weaknesses tested by examining three case studies of union-community relationships involving the peak trade union council in NSW, Australia (Unions NSW). These case studies examine the three types of relationships in order, firstly considering the ad hoc relationships of Unions NSW's weekly council meetings; secondly exploring the 2003 Walk against the War Coalition, an example of a simple coalition relationship; and finally, considering an example of deep engagement with the NSW Transport Alliance.

These case studies are based on a combination of participant observation, interviews and document analysis. I interviewed 10 representatives from Unions NSW and the Rail Bus and Tram union, as well as analyzing relevant Unions NSW documents including council meetings, internal correspondence and annual reports. The research is impacted by the fact that I was a full time employee and officer of Unions NSW during October 2002 and February 2004 (and I continue to work part-time for Unions NSW). My close proximity to the organization is important to acknowledge, as it potentially creates a closeness to the data that may limit a perspective that often comes through distance. However, for the purposes of this research, this closeness is arguably a significant strength. The purpose of the research is to establish how different forms of union-community relationships are effective and useful for unions. Having worked intimately with Unions NSW, particularly during a time of change, my work with the organization assists an understanding of whether this is the case. My employment also enhances my analysis as it allows me to contextualize individual unioncommunity relationships on a long time scale. In addition, my proximity 
to the organization also provides the opportunity for understanding the complexity of informal connections as well as formal documentation, which is a important given that coalitions are strengthened or weakened by the presence or absence of both these types of connections. The fact that I have attended over 100 Unions NSW weekly meetings, that I participated in all the Walk against the War Coalition meetings and events between October 2002 and May 2003, and that I was involved in numerous strategy meetings around the transport campaign provides this study with a distinct perspective on union action and strategy, and the potential and limits of union-community relationships.

Unions NSW was formed in 1871 and is the oldest trade union central council in Australia. It has always had most NSW unions as its affiliates, making it strong and influential amongst the labour movement (Markey, 1994). It has a mixed history of union-community relationships. During the heights of the cold war, the NSW Labour Movement was embroiled in factional tensions between Communist and left-ALP unions versus rightwing (Catholic) ALP aligned unions (Robinson, 2000). These factional battles were intense given the close proximity between the union movement and the Australian Labor Party (ALP). Furthermore, because most social movements were connected to communist and left-labour activists, and because Unions NSW was a leading voice in the right-wing of the ALP, Unions NSW had a distant and often critical view of community organizations and social movements (Dodkin, 2001).

However, social and industrial changes have provoked Unions NSW to reconsider its strategy over the last 10 years. The end of the cold war thawed relations between 'left' and 'right within the NSW Labour Movement, articulated as a desire to become a non-factional movement and break down barriers between 'left' and 'right' unions (Norrington, 1999; Dodkin, 2001; Lane, 2002; Christodoulou, 2003; Robertson, 2003; Bravo, 2004). The attempt to build bridges between the left and the right reduced many of the obstacles to Unions NSW reaching out to progressive groups such as community organizations. In addition, the rapid decline of the union movement from the lofty heights of 50\% union density in 1972 to $23 \%$ in 2004 created additional pressure to turn to community organizations as a strategy to build power to win disputes (ACTU, 1999).

A critical factor influencing the change of strategy of the NSW Labour Movement was the 1998 MUA dispute. The 1998 Australian waterfront dispute involved Patrick Stevedores Operations locking out its unionized workforce, and replacing it with non-union labour. This attack on unionized waterfront workers was a symbolic attempt by the Federal Liberal Government to break strong unionism in Australia (George, 1998). A key strategy used by the Maritime Union was the establishment of 
community pickets, managed by union and community leaders (Trinca and Davies, 2000; MUA, 2002). Phone trees of thousands of activists brought students, unionists and community organization members to the pickets on demand. The community picket on Patricks was critical to the success of the MUA campaign. Despite the employer's use of non-union labour, the picket was able to block trucks going in and out of the premises (MUA, 2002). On its own, the MUA faced almost certain loss; they needed the support and assistance of unionists, community organizations and the public at large to run the pickets. ${ }^{1}$ The successful community outreach strategy was a public demonstration to all unions that union power can be effectively supplemented by community support (Morey, 2004). It was in this context that union-community relationships evolved within the NSW Labour Movement.

\section{Ad Hoc Relationships: Unions NSW's Weekly Thursday Night Meetings}

Unions NSW's history at the centre of a dynamic and tension filled union movement has always ensured that its meetings were a centre point of union debate. Since its formation, Unions NSW has hosted weekly Thursday night meetings of union leaders, described as the 'Parliament of the Union Movement' (Unions NSW, 2004b). In particular, during the factionalized Cold War period, Unions NSW meetings were always full, with left and right maximizing participation to extend influence and control (Dodkin, 2001).

However, the 1990s brought significant challenges to the union movement. Union density fell and the ALP began to discuss the need to separate itself from unions, which combined took significant influence away from peak councils (Dodkin, 2001; Cooper, 2003; Briggs, 2004). However, in its attempt to forge industrial unity over factional conflict, Unions NSW played an instrumental role in several union victories including a battle against electricity privatization that was attempted by the NSW ALP Government (Dodkin, 2001). This dispute helped Unions NSW re-establish influence with the movement by acting as a central arbiter of industrial (not simply factional) needs. ${ }^{2}$

The easing of factional tensions however, created an organizational crisis for the weekly meetings of Unions NSW. Attendance at these meetings

1. Particularly as the Australian Industrial Relations Commission ordered MUA officials to not play a role in organising the pickets (MUA, 2002).

2. This culminated in the vote on electricity privitisation at ALP State Conference where a united union movement, led by the Labor Council, voted against the Government's plans. 
had previously been fuelled by factional brawls between the left and the right. Yet, with an emerging factional consensus, and a growing tendency for Unions NSW leaders to guarantee support for both left and right motions at Executive meetings staged before the Council, attendance began to drop.

However, from 1998 the leadership of Unions NSW changed the orientation of Unions NSW's weekly meetings, focusing them on social issues as well as industrial issues. Council meetings slowly became a site to discuss social issues, beyond the confines of internal union business. In 1999 Michael Costa, the then Secretary used Thursday night meetings to call for a social audit of Government services (Costa, 1999). This culminated in a one-off conference with the Ethnic Communities Council of NSW and the National Council of Social Services (Costa, 1999). This practice deepened under the current Secretary John Robertson, with Council meetings institutionalizing reports and guest speakers from community organizations, including the National Council of Churches, Charities and the National Union of Students (Robertson, 2002). The meetings built ad hoc solidarity, allowing community organizations to enter the 'belly of the (union) beast' and directly address the senior officers of most NSW unions.

While important, this practice was not transformative and the relationships forged were often relatively limited. A motion at Unions NSW is almost a rite of passage for preliminary 'community' engagement with unions rather than a method for forging a deep connection. However the space is important, because it creates the possibility for stronger links. For instance, the National Union of Students used opportunities created by speaking at Unions NSW in 1999 to engage unions in their education campaign, and for the unions to in turn develop student participation in rallies against industrial relations reforms (Heath, 1999). More recent coalitions around Medicare and education fees were also initiated by motions at Unions NSW weekly meetings (Robertson, 2003).

The decline of Unions NSW traditional industrial base caused it to transform its weekly meetings into a space for episodic engagement with community organizations. This change created a useful space for solidarity, which has at points led to deeper engagement between organizations.

\section{Simple Coalition Relationships: The Peace Campaign}

Parallel to the shift in Unions NSW meetings has been a rapid expansion in the number of structured relationships that Unions NSW has pursued with community organizations. Since 2001 and the accession of John Robertson to Secretary, the Council has become a hub of union-community coalition practice. This case study explores the largest of these coalitions, the Walk against the War Coalition, which formed in opposition to the US proposed invasion of Iraq, and engaged Unions NSW in late 2002 and early 2003. 
The Walk against the War Coalition supported one of the most objectively successful social movement mobilizations in Australian history (Palm Sunday Committee, 2003). It was a community initiated coalition formed in September 2002 that brought together three previously autonomous anti-war groupings. Unions NSW and many of its affiliates played an active role in the coalition's formation and its subsequent weekly meetings. There were over 90 groups who participated in the coalition, with around 15 unions at its peak (Sydney Peace and Justice Network, 2004). Meetings were large, with over 120 people drawn together when debates were contentious. ${ }^{3}$ The Coalition was responsible for organizing the major rallies during the anti-war movement, in particular the 300,000 person march on February 16, the 30,000 person rally the day war was declared, the 50,000 person march several days later, and the 20,000 person strong Palm Sunday March (Sydney Peace and Justice Network, 2004). The Coalition also supported the formation of a series of local peace groups-around 20 in total, hosted an organizing conference for the peace movement and managed a series of large email lists to facilitate communication. ${ }^{4}$

The union movement was active in the coalition. Unions NSW and affiliates committed significant resources to the campaign, providing financial resources (such as photocopying facilities, an office space for the coalition, money for advertisements to publicize rallies), human resources (dedicating several staff to organize for the campaign full time) and political influence to assist the organization of rallies and negotiations with council, police and the Government. Unions NSW also sought to mobilize union members on the question of peace and war. Unions NSW organized a 'unionist' march to the large Feb 16 rally, with over 15,000 unionists meeting in Town Hall Square. There was a public 'Unions work for Peace Campaign' with union sites declaring themselves peace sites at stop work meetings and wearing badges for peace (Lewis, 2003).

The alignment of Unions NSW with the community coalition Walk against the War can be described as a simple coalition relationship. Union participation critically strengthened the capacity of the peace movement, giving the coalition greater capacity, legitimacy and success. Yet the relationship between these community organizations and the union movement was distant. Unions NSW and other unions participated in these coalitions via officials and representatives. Although several unions sought

3. Contentious here both refers to important points of struggle in the movement (such as the impending upsurge before February 14, but also when fractures appeared in the coalition between traditional church and union groups and more radical, "socialist" or Trotskyist organizations. It was this tension that ended up dividing the group, as the group dissolved and split into two organizations after the formal war had ended in May 2003.

4. These email lists had over 5000 subscribers in total. 
to mobilize their membership to attend rallies, there was only limited union member participation. The unions' work for peace day materials were often kept in union offices and not distributed to workplaces. While union council of management meetings passed motions against the War, there was not a shift by unions to organizing on the issue of peace or to use their industrial power to influence the Government. The union's greatest focus was organizing in partnership with community organizations rather than developing union rank and file support. Indeed, as Clawson notes, community alliances substitute at times for organizing work within the rank and file of the union movement (Clawson, 2003) In addition, even though Unions NSW embraced a vision 'beyond wages and conditions' in campaigning for peace, there was still a sense in the unions that this issue was peripheral to the 'real business' of contract bargaining.

This relationship was similar to the typography for a communityinitiated simple coalition relationship. Unions NSW participated in a formal coalition, represented by staff with several mobilizations of union members. This issue was an important social issue, but its relative distance from the material experiences and workplace conditions of trade union members contributed to limited union member participation. Compared to wages, peace is an abstract issue; it is not in the direct self-interest of unions as organizations or easily translatable to the day-to-day experiences of union members. This issue provided a limited capacity to engage, mobilize and expand the political conscious of union members. The lack of interest engagement helps explain the limited union participation in this coalition.

Union participation significantly increases the capacity of a coalition, yet coalitions alone are not a panacea for creating union power or deep relationships. While coalitions provide a space for cross-organizational planning, they do not provide significant space to engage workplace leaders in decision making as they limit decision making to officials (Clawson, 2003). On their own, coalitions have a limited capacity to change unions or engage union power. Coalitions tend to engage union leaders and officials rather than sparking union activism within the membership. Without membership engagement, coalitions do not effectively activate the depth of power that unions possess. Within coalitions, unions often act like another community organization, albeit one with a large number of resources. Coalitions may enhance community campaigns, but they do not necessarily and directly engage or enhance union power.

\section{The Transport Alliance: Deeply Engaged Relationships}

In the wake of community campaigns such as the peace campaign, and in an environment where peak councils play a pivotal role in the shift to organizing, Unions NSW is also revising how it engages with its union 
industry groups, such as in transport and rail (Cooper, 2003). Unions NSW has had a long history of working closely with the rail unions (Morey, 2004). Yet this relationship has until recently been unremarkable, providing industrial support to unions working in essential services, rather than facilitating a broader agenda.

Recently, two key public transport unions have engaged in a process of change. In the political spectrum of Australian labour, the Rail, Bus and Tram Union (RTBU) is traditionally a strong right-wing union and the Australian Services Union (ASU) is a smaller left wing union. Although the industry has a jurisdictional demarcation, up until recently it was categorized by raiding and disagreement. In 2001 this tension was diffused through a solidarity pact signed by the two leaders, committing the unions to working together (Carruthers, 2004). Within each union there has been significant organizational change. In 2001 the NSW Branch of the RTBU hired an experienced delegate educator, who had experience running union education programs for union stewards, who was charged with assisting the union to shift away from a servicing model of unionism focused on grievance handling towards an organizing model of unionism focused on workplace leaders and growth (Carruthers, 2004). This was soon successful, with a bargaining campaign in the Rail Infrastructure Corporation rapidly expanding union density and workplace leadership, achieving a remarkable ratio of one activist to every ten members (Carruthers, 2004). Similarly, the ASU shifted to embrace organizing. Within its Transport Division, there has been an internal restructure, creating a series of new branches, members and delegates. The Division, which was formerly a centre for grievance handling, employed a group of young, experienced, trained organizers.

These organizational shifts coincided with an aggressive push by the State Government. After the State Election in April 2003, the former Secretary of Unions NSW Michael Costa, now a Member of Parliament, was given the Transport Portfolio and set about restructuring the rail industry. His plan was to 'downsize' the workforce to make public transport selfsufficient and cost effective (Campbell, 2003; Morey, 2004). Fares were to increase, rural services were to be cut-the sector was to be transformed.

Unions NSW played a leadership role in convening a joint unioncommunity response, beginning with a community vision for transport. In response to the Government's aim for downsizing transport, the unions invited organizations that had made submissions to the Inquiry to contribute to a broader alternative Report (Campbell, 2003; Morey, 2004). Submissions were received from over 39 organizations, including unions, councils, peak environmental and community advocacy groups (Campbell, 2003). The Report, entitled Our Public Transport: A Community View focused on the fundamental role of public transport as an essential service (Campbell, 
2003). It argued that an effective public transport system would be based on dual aims - the provision of high quality, accessible services, delivered by a highly trained workforce. The report continually linked the needs and interests of those who catch public transport and those who work in public transport.

The report was launched as a joint initiative by union and community organizations at NSW Parliament House, the seat of the NSW State Government, in Sydney in early December 2003. The event was cosponsored by the unions, the Western Sydney Regional Organization of Councils (WESROC) and researchers from the University of Technology's Department of Sustainable Futures. It reacted to the Government's inquiry while opening up a public debate on transport. Moreover, it placed key union and community organizations at the centre of an alternative community vision for transport, focusing on the important place that unionized, active transport workers have in the provision of high quality transport services (Campbell, 2003).

The issue of transport was opportunity rich, and over the summer months it escalated into a "rail crisis" (Grimm, 2004). Problems included growing anger about the restructure, health testing, safety problems, rank and file unrest and aggressive managerialism. Poor management was highlighted by a driver shortage which caused major rail delays. Transport was repeatedly front-page news and train delays were the norm. Public anger grew, and Costa, the former unionist, began attacking the union. Knowing it would be unable to gain community support on its own, the RTBU sought cross-union support and then moved to form a community coalition in 2004 (Unions NSW, 2004b).

The Transport Alliance was formed on 12 Feb at the peak of the rail crisis (Morey, 2004). The initiating organizations were those organizations who had put in submissions to the community reports. The aim was to form a longer-term relationship around public transport policy while also reacting to the immediate crisis. Thus the Alliance called for an urgent Summit to deal with the state's transport needs. It also began to map out joint priorities for a longer-term community campaign, using the community report to create a policy agenda. The Alliance was formed with long term goals, charged with coordinating a three-year transport campaign, focused on the union's 2004 contract negotiations and then the 2007 State Election (Morey, 2003, 2004).

Union engagement in the transport campaign deeply engaged union members because the public transport campaign was directly connected to the union's contract campaign. In the lead up to bargaining, Unions NSW assisted the RTBU and ASU to create a single bargaining unit of 
all rail unions and a combined union bargaining committee to prepare a log of claims (Hayden, 2004; Morey, 2004). Between May and October the unions escalated activity, solidifying a commitment from members through workplace meetings, badge days, stop works and finally a rally (Morey, 2004).

The deep union activity also reached outwards to local community groups in regional areas of NSW. In transport centres such as Murwillumbar on the North Coast and on the South Coast, unions helped to form local union-community groups that publicly campaigned against threatened cuts to rail services (Carruthers, 2004; Morey, 2004).

According to the leadership of the RTBU, the formation of the transport alliance and the deep union engagement in the 2004 contract negotiations represented the deepest form of collective organizing that had happened in twenty years (Hayden, 2004). The issue of transport was ripe for both deep union engagement and broad community engagement. Transport unions have a ready self-interest in transport funding. Similarly, community organizations such as WSROC, representing Western Sydney Municipal Councils, and the Western Sydney Community Forum, which represents welfare advocacy organizations in Western Sydney, had a direct interest in transport services, given the poor level of current service in the Western Suburbs. In addition, the issue readily engaged environmental organizations, who have long campaigned for alternatives to cars. The alignment of mutual interest created a basis for deep, long-term relationships.

Yet, the more recent history of the Transport Alliance demonstrates that issue alignment is not always enough to build a trusting, long-term coalition structure. When the unions began to intensify their engagement in the bargaining campaign, the Alliance met less frequently. There was some hesitation amongst the unions about how to most effectively engage in the Alliance (Morey, 2004). While there might be a broad common interest across the organizations to support public transport, each of the organizations had very different specific issues that they prioritized. Even the unions did not have a consensus position on the future for transport (Hayden, 2004). Furthermore, in the midst of an enterprise bargaining campaign, it was difficult for the unions to provide resources to developing a vision while there was membership pressure to focus on the future conditions of employees within the rail industry (Morey, 2004). While there is a consensus that the future activities of rail unions require an increased role for setting the agenda for public transport (Carruthers, 2004; Hayden, 2004; Morey, 2004), there is a sense that this task is a future, not an immediate priority.

The groundwork that has been established through the Transport Alliance has many points in common with the criteria for deeply, engaged 
relationships. The Alliance sits alongside a deeply organized workplace, with delegates and the rank and file actively involved in decision-making and mobilization around the enterprise bargaining campaign. Furthermore, the Alliance is in the mutual self-interest of participating organizations, providing unions with the capacity to bargain for better conditions at work and providing community organizations and local communities with the capacity to improve the quality of public transportation (Clawson, 2003; Fine, 2003). The Alliance has established a formal structure backed up by a research capacity and a long term campaign around the social concern of public transport (Banks, 1992). Furthermore, Mark Morey who worked at Unions NSW has personal experience in both the community sector and the union movement and is able to act as a bridge builder between these two cultures to help build consensus (Estabrook, Siqueira et al., 2000; Rose, 2000). Issues of place and scale have also supplemented the work of the Alliance, as the union was able to forge community alliances in local, regional areas more easily than in metropolitan Sydney, where the rail needs were immediate and commonly shared (Hayden, 2004; Morey, 2004). On the criteria, the Transport Alliance reinforces the elements of deeply engaged relationships.

The Transport Alliance is better described as having the potential for deep engagement rather than exemplifying it. According to my interview, there is still work to be done to connect union delegates to the vision for public transport. The vision and framing of union demands as community issues is understood by the leadership, but is not an issue debated amongst the membership (Carruthers, 2004; Hayden, 2004; Morey, 2004). The politicization and political mobilization of the membership have been confined to issues focused on the status of employees in the industry, which has connected the workers future, to the future of rail (Carruthers, 2004). This importantly may be an intermediary step between simple "wages and conditions' consciousness, and a community focus. The focus of the unions is on developing and organizing its members to act as a union, as several RTBU officials commented, 'we are teaching them to be union' (Carruthers, 2004; Hayden, 2004). This commitment to collective action may be a prerequisite to more radical action around public transport more broadly, an example of the union 'organizing ourselves before we organize anyone else' (Carruthers, 2004). The unions have prioritized connecting the workers to their industry, and then plan to extend this collective common interest to a community vision for the transport industry.

The potential for vibrant and deep union-community relationships is real. The RTBU recognizes that political education and political action will be a crucial feature of future Transport Union action. Indeed, the RTBU at their 2004 September Council made a financial commitment to change how 
it 'does politics' and to redirect much of its political donations away from the ALP to an internal political action fund focused on political education and mobilization around the 2007 State Election (Carruthers, 2004; Hayden, 2004). There is also a commitment to increasing the resources and work with local community groups, particularly in regional areas. As the President Bob Hayden acknowledged, the union is prepared to resource local community action, as local transport groups acting with the unions create far more pressure and influence against the Government and with the general public than the union acting alone (Hayden, 2004).

The Transport Alliance demonstrates the possibilities for deeply engaged union-community relationships. The issue that underpins this Alliance mutually engages union and community partners, and deeply connects to a worker vision for the transport industry. The union has combined an internal renewal program with its attempts to engage community relationships. This case study highlights that a shift towards deeper, long-term unioncommunity engagements is both a horizontal process across organizations to build trusting relationships oriented towards a long-term agenda, as well as a deep process, to build capacity inside unions in order to activate union power in support of a vision for public transport.

\section{DISCUSSION AND CONCLUSION}

Strategies for union renewal increasingly consider how unions can engage allies in the process of rebuilding union power. This paper has explored a continuum of the types of relationships that unions and community organizations can develop that distinguishes between the types of tactical and strategic power that these organizational forms can deliver for campaigns and for unions.

The framework is a three-fold categorization of union-community relationships that attempts to distill the key elements that vary unioncommunity engagement. First are ad hoc relationships, which provide unions with the opportunity to harness the social power of community organizations when faced with the need to react and create familiarity that can be the basis for future relationships. Secondly are simple coalition relationships, which institutionalize relationships, allowing organizations to negotiate and plan. However, the simple formal nature of these relationships creates an unbalanced engagement; as in the case of a community-initiated coalition, it is sometimes difficult to deeply engage unions in a simple coalition. A more long term equal form of engagement occurs in deeply engaged relationships, where a mutual-interest alignment and a permanent structure allow for partners to plan a long-term campaign strategy, letting relationships develop and grow. Furthermore, with deeply engaged 
relationships, the engagement is not just horizontal but deep, particularly in relation to the union, where the union seeks to develop the skills, interest and politicization of its membership in the process of advancing the coalition's agenda.

As the union movement continues to renew its strategies and practices and rebuild unionism, it is likely that unions will continue to increase the trend of reaching out to community organizations to enhance their capacity and their power. As this paper suggests, the process of reaching out is not only useful to maximize a union's capacity to achieve objective victories, but is also essential for unions to again be the central agents for improving the livelihood of working people, both inside and outside the workplace. This paper seeks to contribute to this reaching out process by providing a typology that is a guide for the various forms of union-community relationships that can underpin the trend towards more widespread coalition practice. It highlights that union-community relationships and coalitions are not all the same, and that different types of relationships will be strategically useful depending on the form of action and type of power desired. It also argues that union-community relationships cannot be abstracted from debates around internal union reform, because examples of deeply engaged union-community relationships are likely to coexist with a program of workplace leadership development and politicization.

\section{REFERENCES}

ACTU. 1999. Unions@Work. Melbourne: Australian Council of Trade Unions.

BANKs, A. 1992. "The Power and Promise of Community Unionism." Labor Research Review, 18, 16-31.

Bravo, C. 2004. "Interview with Peter Lewis Labor Council's Chief Troublemaker Chronicles the Battles of the Past Year and Ponders those Still to Come." <http://www.yap.com.au/channels/politics/article/1223.html>, accessed 7 September 2004.

Brecher, J. and T. Costello. 1990a. Building Bridges: The Emerging Grassroots Coalition of Labor and Community. New York: Monthly Review Press.

Brecher, J. and T. Costello. 1990b. "American Labor: The Promise of Decline." Building Bridges: The Emerging Grassroots Coalition of Labor and Community. J. Brecher and T. Costello, eds. New York: Monthly Review Press.

BRIGgS, C. 2004. "The End of a Cycle? The Australian Council of Trade Unions in Historical Perspective." Peak Unions in Australia: Origins, Purpose, Power and Agency. B. Ellem, R. Markey and J. Shields, eds. Sydney: The Federation Press. 
Bronfenbrenner, K. and T. Juravich. 1998. "It Takes More than House Calls: Organizing to Win with a Comprehensive Union-Building Strategy." Organizing to Win: New Research on Union Strategies. K. Bronfenbrenner et al., eds. Ithaca: ILR Press.

Campbell, S. and S. White. 2003. Our Public Transport: A Community View. Sydney: UTS Institute for Sustainable Futures.

CARruthers, L. 2004. "Unstructured Interview with Research/Education Officer, Rail Tram and Bus Union, NSW Branch.” Thursday 21 October, Sydney.

Christodoulou, C. 2003. "Factional Free-For-All." Workers Online, <http:// workers.labor.net.au/features/200304/a_guestreporter_chris.html>, accessed 7 September 2004.

Clawson, D. 2003. The Next Upsurge: Labor and the New Social Movements. Ithaca: ILR Press.

Cooper, R. 2003. "Peak Council Organising at Work: ACTU Strategy 19942000." Labour \& Industry, 14 (1), 1-15.

CostA, M. 1999. "Labor Council Annual Report 1999." Sydney, Labor Council of NSW, <http://www.council.labor.org.au/annual_reports/1999/>.

CRAFT, J. 1990. "The Community as a Source of Union Power." Journal of Labor Research, 11 (2), 145-160.

De Martino, G. 1999. "The Future of the US Labor Movement in an Era of Global Economic Integration." Labour Worldwide in the Era of Globalisation: Alternative Union Models in the New World Order. R. Munck and P. Waterman, eds. Hampshire: Macmillan.

Dodkin, M. 2001. Brothers: Eight Leaders of the Labor Council of NSW. Sydney: University of New South Wales.

EISENSCHER, M. 1999. "Critical Juncture: Unionism at the Crossroads." Which Direction for Organised Labor? Essays on Organising Outreach and Internal Transformation. B. Nissen, ed. Detroit: Wayne State University Press.

Ellem, B. 2003. "New Unionism in the Old Economy: Community and Collectivism in the Pilbara's Mining Towns." Journal of Industrial Relations, 45 (4), 423-441.

Ellem, B. 2005. "Dialectics of Scale: Global Capital and Local Unions in Australia's Iron Ore Industry." Economic and Industrial Democracy, 26 (3), 335-358.

Estabrook, T., C. Siqueira, et al. 2000. "Labor-Community Alliances in Petrochemical Regions in the United States and Brazil: What Does it Take to Win?" Capitalism, Nature, Socialism, 11 (3), 113-145.

FINE, J. 2003. "Community Unions in Baltimore and Long Island: Beyond the Politics of Particularism." Political Science. Boston: Massachusetts Institute of Technology.

Freeman, R. and J. Rogers. 2002. “A Proposal to American Labor: Let's Create 'Open-Source Unions' and Welcome Millions into the Movement." The Nation, June 24, 18-24. 
George, J. 1998. "The MUA Dispute: The Conservative Agenda for IR in Australia.” ACTU News, <http://www.actu.asn.au/public/news/1052977030_ 32636.html>, accessed 7 September 2004.

Grimm, N. 2004. "More Train Service Disruptions for Sydney." World Today. Australia, ABC 702 News, Thursday, 12 February, 12:38:20.

Hayden, B. 2004. "Unstructured Interview, President Rail Tram and Bus Union." Sydney, 21 October.

HeAtH, R. 1999. "Tales from the Frontline: Voluntary Student Unionism." Workers Online, <http://workers.labor.net.au/14/d_review_uni.html>.

HeRoD, A. 1998. Organising the Landscape: Geographical Perspectives on Labor Unionism. London: University of Minnesota Press.

JoHnSTON, P. 1994. Success while others Fail: Social Movement Unionism and the Public Workplace. Ithaca: ILR Press.

JonAs, A. 1998. "Investigating the Local-Global Paradox: Corporate Strategy, Union Local Autonomy and Community Action in Chicago." Organising the Landscape. A. Herod, ed. Minneapolis: University of Minnesota Press.

LANE, T. 2002. "The National Interest: Interview with John Robertson." Radio National, 24 November.

LEwIS, P. 2003. “Unions Work for Peace Day.” LaborNet, <http://www.labor. net.au/campaigns/nowar/news/action.html>, accessed 8 September 2004.

LiPsig-Mumme, C. 2003. "Forms of Solidarity: Trade Unions and Community Unionism." ACTU News, <www.actu.asn.au/organising/news/1053579943_ 13456.html>.

Markey, R. 1994. In Case of Oppression: The Life and Times of the Labor Council of New South Wales. Sydney: Pluto Press.

Moody, K. 1997. Workers in a Lean World. London: Verso.

Morey, M. 2003. "NSW Transport Alliance, Labor Council of NSW." Labor Net, <http://www.labor.net.au//campaigns/NSWTA//NSWTA.html>, accessed 10 October, 2004.

Morey, M. 2004. "Structured Interview, Officer Labor Council of NSW." Sydney, Wednesday 20 October.

MUA. 2002. "War on the Waterfront." MUA Website, <http://mua.org.au/war/ mobilisation.html>, accessed 7 September 2004.

Munck, R. and P. WATERMAN. 1999. Labour Worldwide in the Era of Globalisation: Alternative Union Models in the New World Order. Hampshire: Macmillan.

Nissen, B. 2000. "Living Wage Campaigns from a "Social Movement" Perspective: The Miami Case." Labor Studies Journal, 25 (3), 29-50.

NissEn, B. 2004a. "The Effectiveness and Limits of Labor-Community Coalitions: Evidence from South Florida.” Labor Studies Journal, 29 (1), 67-89.

NisSEN, B. 2004b. "Labor-Community Coalition Strengths and Weaknesses: Case Study Evidence." Partnering for Change: Unions and Community Groups Build Coalitions for Economic Justice. D. Reynolds, ed. Armonk: M.E. Sharpe. 
Norrington, B. 1999. "ALP Must Educate the Party Faithful to End Old Factional Wars." Sydney Morning Herald, Sydney, 17.

ОвАсн, B. 2004. Labor and the Environment Movement: The Quest for Common Ground. Cambridge, Mass.: MIT Press.

Palm Sunday Committee. 2003. "Massive Anti-War Protests in Australia, Feb. 14-16." Palm Sunday Committee Website, 17 February, <http://palmsunday. socialchange.net.au/news/39.html>, accessed 21 April 2006.

Reynolds, D. 2004. Partnering for Change: Unions and Community Groups Build Coalitions for Economic Justice. Armonk, N. Y.: M. E. Sharpe.

Robertson, J. 2002. "Labor Council of NSW Annual Report 2002." Sydney, Labor Council of NSW, <http://council.labor.net.au/annual_ reports/2002/2002-2002-3.html>.

RoberTSOn, J. 2003. "Labor Council of NSW: Annual Report.” Sydney, Labor Council of NSW, <http://council.labor.net.au/annual_reports/2003/2003printversion.html>, accessed 7 September 2004.

RoBINSON, I. 2000. "Neoliberal Restructuring and US Unions: Toward Social Movement Unionism?" Critical Sociology, 26 (1/2), 109-138.

Rose, F. 2000. Coalitions Across the Cultural Divide. Ithaca: Cornell University Press.

SAVAGE, L. 1998. "Geographies of Organising: Justice for Janitors in Los Angeles." Organising the Landscape: Geographical Perspectives on Labor Unionism. A. Herod, ed. Minneapolis: University of Minesota Press.

Sydney Peace And Justice Coalition. 2004. "About the Walk against the War Coalition." Sydney Peace and Justice Network, <http://www.nswpeace. org/about/1047892706_4931.html>, accessed 14 April 2006.

TArrow, S. G. 1994. Power in Movement: Social Movements, Collective Action and Politics. Cambridge, UK: Cambridge University Press.

TAtTersall, A. 2005. "There is Power in Coalition: A Framework for Assessing How and When Union-Community Coalitions are Effective and Enhance Union Power." Labour and Industry, 16 (3), 97.

Tattersall, A. 2006a. "Common Themes in Community Unionism in Industrialised Countries: Lessons from Long Term Coalitions in Australia and Canada." European Group on Organizational Studies Colloquium. Sub-theme 38: Organizing Labor and New Social Movements in an Era of Globalisation, Bergen, Oslo, 7-9 July.

TAtTersall, A. 2006b. "Solidarity Whenever? A Framework for Understanding when Unions Are Likely to Join Long-Term Union-Community Coalitions." Socially Responsive, Socially Responsible Approaches to Employment and Work. Monash University Prato Centre, Tuscany, Italy, 1-4 July.

Tattersall, A. 2006c. "Bringing the Community In: Possibilities for Public Sector Union Success through Community Unionism." International Journal of Human Resource Development and Management, 6 (2/3/4), 186.

TatTersall, A. 2007. "Variations in Union-Community Coalitions: A Look at Union Engagement in NSW." Unions and Community. D. Buttigieg et al., eds. Melbourne: Heidelberg Press. 
TrincA, H. and A. DAvies. 2000. Waterfront: The Battle that Changed Australia. Milsons Point: Doubleday.

TuFTs, S. 1998. “Community Unionism in Canada and Labor's (re)organization of Space." Antipode, 30 (3), 227-250.

Unions NSW. 2004a. "Labor Council Meeting, Minutes 12 February 2004." Sydney, Labor Council of NSW, <http://council.labor.net.au/ minutes/9520040212.html>, accessed 21 October 2004.

UNIONS NSW. 2004b. "Labor Council Structure." Sydney, Labor Council of NSW, <http://www.council.labor.org.au/about_us/lcnsw_structure.html>, accessed 15 October 2004.

Walsh, J. 2000. "Organising the Scale of Labor Regulation in the United States: Service-Sector Activism in the City." Environment and Planning, 32 (9), 1593-1610.

Waterman, P. 1999. "The New Social Unionism: A New Union Model for a New World Order." Labour Worldwide in the Era of Globalisation: Alternative Union Models in the New World Order. R. Munck and P. Waterman, eds. Hampshire: Macmillan.

Waterman, P. and J. WiLls. 2001. "Introduction: Place, Space and the New Labor Internationalisms: Beyond the Fragments?" Place, Space and the New Labour Internationalisms. P. Waterman and J. Wills, eds. Oxford: Blackwell.

WILLS, J. 2002. Union Future: Building Networked Trade Unionism in the UK. Glasgow: Bell and Bain.

\section{RÉSUMÉ}

\section{La construction de liens avec la communauté et le renouveau syndical en Australie}

En réaction au déclin de leur densité et de leur influence, les syndicats en Australie, tout comme dans d'autres économies de marché, ont tenté d'établir des rapports avec les organisations de la communauté. Pour rendre compte de cette tendance, dans le langage et les pratiques syndicales, des termes ont été retenus tels que le syndicalisme communautaire, la coalition syndicat-communauté, le syndicalisme de type mouvement social. Cependant, il existe peu de cadres de référence qui puissent décrire les différentes façons dont les syndicats et les organismes communautaires vont s'obliger les uns envers les autres. Cet essai se veut une tentative de corriger cette lacune. Il analyse trois types différends de relations syndicatcommunauté (des rapports ad hoc, des rapports simples et des relations plus solidement engagées) en délimitant et en décrivant leurs pratiques 
et leur potentiel d'accroissement du pouvoir syndical. Je définis chacun de ces concepts en retenant quatre variables clés des rapports syndicatcommunauté : une préoccupation commune, la présence d'une structure, d'une mesure et enfin la participation syndicale (Tattersall, 2005). Cet essai nous permet de penser que cette pratique étendue des rapports syndicatcommunauté peut être décrite en termes de syndicalisme communautaire (Tattersall, 2007).

Le cadre de référence débute avec les rapports ad hoc, caractérisés par une action conjuguée face à un événement, sans aucune structure formelle de coalition, mais qui peuvent fonctionner à n'importe laquelle échelle territoriale, alors que la participation du syndicat serait soit dominante, si elle est initiée par le syndicat même, soit instrumentale et en surface, si elle est enclenchée par la communauté.

En deuxième lieu, on aborde les rapports simples de coalition, qui peuvent survenir à propos de n'importe lequel enjeu faisant l'objet d'une préoccupation commune et, alors, cela peut être initié par le syndicat ou par la communauté. La différence se situe ici au plan de la structure des rapports qui implique la mise en place d'une structure formelle de rencontres. Si la coalition origine du syndicat, il existe alors une tendance vers une domination syndicale. Si elle est enclenchée par la communauté, on assiste alors à une faible participation de la part du syndicat. La participation syndicale tend à se situer à l'échelle des représentants et du personnel, au lieu de faire appel aux délégués d'atelier ou encore aux salariés de la base.

En troisième lieu, on traite des rapports qui obligent les gens en profondeur et qui sont basés, d'une manière remarquable, sur des enjeux d'intérêts mutuels à la fois pour les syndicats et les organismes communautaires. Les points chauds au cœur de ces rapports sont aussi publicisés en y ajoutant une vision sociale élargie. En termes de structure, il existe une tendance à ne retenir qu'un groupe restreint de partenaires organisationnels, avec la présence de personnes capables d'établir des ponts, parce qu'elles ont déjà une expérience du syndicalisme et des mouvements sociaux, et aussi une capacité de participer avec des travailleurs de la base dans des structures décisionnelles. Des rapports profondément engagés se situent à des niveaux multiples et vont possiblement se présenter dans des entreprises à capital fixe, dans les services privés, les mines ou dans le secteur public. La participation du syndicat est accrue dans ce type de rapports, associée à un engagement financier important, un engagement du personnel syndical et de celui des travailleurs de la base.

Au fur et à mesure que les rapports s'approfondissent, au passage de rapports $a d$ hoc à des rapports simples et enfin à des rapports plus intenses, ils prennent pour les syndicats la forme de rapports communautaires mutuels 
viables. Cependant, ces catégories, tout en étant distinctes, ne sont pas absolues : elles fonctionnent sur un continuum d'une pratique de coalitions possibles. De plus, il ne faut pas penser qu'une forme de coalition est toujours plus efficace qu'une autre. Les coalitions et les rapports syndicatcommunauté sont des mécanismes stratégiques qui constituent un des nombreux éléments dans une perspective élargie de créer et d'exercer de l'influence (Bronfenbrenner et Juravich, 1998). Ce schéma cherche à ventiler les éléments de la relation communauté-syndicat sans laisser croire qu'une forme serait supérieure à une autre. Au contraire, il démontre que, au moment où les relations de type $a d$ hoc peuvent présenter une source d'influence en courte période, si un syndicat adopte une stratégie de longue période pour se bâtir un pôle d'influence, un engagement en profondeur est susceptible de générer une orientation plus efficace pour le syndicat et la campagne (pour la paix).

L'article analyse trois exemples de relations communauté-syndicat impliquant des syndicats de Nouvelle-Zélande (NSW Unions), le conseil central du travail de Nouvelle-Zélande, en Australie. Il cherche à démontrer l'utilité du cadre de référence retenu et la façon dont les éléments identifiés reflètent les forces et les faiblesses de chaque type de relations.

Le premier exemple est celui des rencontres régulières du conseil des syndicats de la Nouvelle-Zélande, qui sont maintenant retenues par le conseil comme étant le médium pour les relations ah hoc communauté-syndicat. Au moment où la densité syndicale était à son sommet, les rencontres du conseil servaient d'espace de débats relatifs à l'industrie. Maintenant, alors que cette densité décline et se réduisent les tensions entre factions, l'orientation des rencontres a été redéfinie. Les leaders des syndicats NSW ont décidé d'en faire un lieu de communication et d'échange avec les organismes communautaires, invitant des conférenciers d'honneur à faire connaître leurs activités et permettant à ces derniers de rencontrer des leaders syndicaux. Ces rencontres ont donc permis, d'une manière efficace, la formation de relations entre les syndicats et les organismes communautaires.

Un deuxième exemple est celui de la participation des syndicats NSW à la Marche de la coalition anti-guerre, en 2003. Les syndicats NSW et d'autres constituaient les participants clefs dans cette coalition de 90 organisations. La coalition a avec succès organisé la plus vaste démonstration de l'histoire de l'Australie. Les syndicats ont intéressé leurs membres à des campagnes pour la paix à teneur spécifiquement syndicale, tout en encourageant les syndiqués à prendre part à des marches plus importantes. Cependant, les syndicats cherchaient à mobiliser la communauté en général plutôt que de s'en tenir à leur propre effectif. La coalition était très vaste et la confiance demeurait alors difficile à maintenir. La coalition a mis sur pied une structure formelle puissante, mais l'absence d'intérêt immédiat des syndicats 
dans l'enjeu de la paix a diminué leur engagement et leur participation dans la campagne.

Le troisième exemple est celui de l'implication des syndicats NSW et les syndicats du transport ferroviaire dans l'alliance du transport. Cette alliance fait partie d'une stratégie, à l'échelle du secteur, des syndicats NSW pour renforcir le syndicalisme dans l'industrie du transport et pour développer une vision communautaire du transport public. La campagne faisait alors appel à une stratégie d'organisation en profondeur au sein du monde syndical, en suscitant des leaders sur les lieux du travail et un vaste conseil de négociation. Elle englobait aussi le projet de l'établissement d'une alliance avec les organismes communautaires et les organisations environnementales. L'implication syndicale dans cette campagne était très intense parce que les syndicats avaient un intérêt immédiat dans la négociation, qui a connu un élargissement dû à une préoccupation pour la gestion du secteur et l'avenir du transport public. La campagne s'est organisée avec succès à l'échelle locale et celle des provinces, plus particulièrement dans les régions de la Nouvelle-Zélande. Cependant, ce n'était pas facile de bâtir des relations fortes avec les diverses organisations, qui ne s'entendaient pas sur les priorités, même si elles avaient des intérêts semblables.

Le cadre de référence comporte une typologie à trois volets des rapports syndicat-communauté qui tentent de diffuser les éléments clefs qui font varier l'engagement communauté-syndicat. D'abord, il y a les rapports $a d$ hoc qui fournissent aux syndicats une occasion d'harnacher l'influence sociale des organismes communautaires, au moment où ils ont à faire face à une nécessité de réagir et de bâtir une atmosphère de familiarité servant de base à des rapports futurs. Ensuite, viennent les relations simples de coalition, qui servent à institutionnaliser les rapports, en permettant ainsi aux organisations de négocier et d'établir des plans. Cependant, la nature simple et formelle de ces rapports engendre une sorte de déséquilibre au plan de l'engagement. Tout comme dans le cas d'une coalition initiée par la communauté, il devient parfois difficile de demander un engagement en profondeur de la part des syndicats dans une simple coalition. Une forme d'engagement plus équilibré en longue période survient dans des rapports profondément enracinés, où l'alignement d'intérêts mutuels et une structure permanente facilitent l'adoption d'une stratégie de campagne de longue période, tout en permettant aux rapports de se développer et de croître. De plus, dans le cas de rapports profondément ancrés, l'engagement s'établit non seulement en surface mais aussi en profondeur, plus particulièrement en relation avec le syndicat, là où il cherche à développer les habiletés, l'intérêt et la politisation de son membership dans le processus de promotion du programme d'action de la coalition. 